\title{
Potensi Ekstrak Kering Belut (Monopterus albus) pada Pengobatan Tukak Lambung
}

\section{The Potential Effects of Eel (Monopterus albus) Dry Extract on Peptic Ulcer Treatment}

\author{
Havizur Rahman", Putri Maya Sari, Indri Maharini, Bilia Ayu Septiana \\ Pharmacy Study program, Faculty of Sains and technology, Jambi University, \\ Jl. Jambi-Muaro Bulian Km 15, Jambi 36122, Indonesia \\ *Corresponding author email: havizurrahman27@unja.ac.id
}

Received 16-10-2019 Accepted 03-04-2020 Available online 15-03-2020

\begin{abstract}
ABSTRAK
Peningkatan konsumsi akohol, obat-obat anti-inflamasi nonsteroid (OAINS), dan diet yang keliru menjadi penyebab meningkatnya penyakit tukak lambung (ulkus peptikum) di seluruh dunia. Penggunaan obat sintetis jangka panjang sering menimbulkan efek yang tidak diinginkan. Belut diketahui memiliki kadar protein yang tinggi, mirip dengan ikan gabus. Penelitian tentang aktifitas ikan gabus dalam pengobatan luka bakar, luka dalam bekas operasi, serta tukak lambung telah banyak dilakukan. Diperkirakan aktifitas tersebut dipromotori oleh kandungan protein dan asam amino dari ikan. Rancangan penelitian yang digunakan adalah rancangan acak kelompok dengan 5 kelompok perlakuan masing-masing 5 ekor tikus. Diperoleh hasil rata-rata titik pendarahan pada kontrol negatif 7,6: kontrol positif 2,6; dosis ekstrak kering belut 100 $\mathrm{mg} / \mathrm{kgBB}$ sejumlah 4,2; dosis ekstrak kering belut $200 \mathrm{mg} / \mathrm{kgBB}$ sejumlah 1 ; dan dosis ekstrak kering belut $400 \mathrm{mg} / \mathrm{kgBB}$ sejumlah 1 . Sedangkan rata-rata $\mathrm{pH}$ cairan lambung pada kontrol negatif 4,948: kontrol positif 5,182; dosis ekstrak kering belut 100 $\mathrm{mg} / \mathrm{kgBB} 4,224$; dosis ekstrak kering belut $200 \mathrm{mg} / \mathrm{kgBB}$ 2,888; dan dosis ekstrak kering belut $400 \mathrm{mg} / \mathrm{kgBB} 4,89$. Secara statistik terdapat perbedaan titik pendarahan yang signifikan antara dosis kontrol positif, 100, 200, dan $400 \mathrm{mg} / \mathrm{kgBB}$ dengan kontrol negatif. Tidak ditemukan adanya korelasi antara $\mathrm{pH}$ dengan timbulnya titik pendarahan, sehingga $\mathrm{pH}$ tidak dapat dijadikan parameter terjadinya tukak lambung. Dapat disimpulkan bahwa ekstrak kering belut memiliki aktifitas sebagai pengobatan tukak lambung dengan dosis terbaik pada $200 \mathrm{mg} / \mathrm{kgBB}$.
\end{abstract}

Kata kunci: belut, ekstrak kering, tukak lambung. 


\begin{abstract}
Consumption of alcohol, the use of nonsteroidal anti-inflammatory drugs, and improper diets are the cause of the increase of peptic ulcer cases worldwide. Since the long-term use of synthetic drugs often causes undesirable effects, the treatment with the natureorigin ones with, which is believed to be safer, is desirable. Eel (Monopterus albus) is known to have high protein content, which is similar to the snakehead murrels. The therapeutic use of snakehead murrel for the treatment of burns, wounds in postoperative scars, and ulcers have been widely evaluated. The proteins and amino acids are considered as the bioactive compounds responsible for the biological activities of the snakehead murrel. The study design was the randomized block, employed five treatment groups of five rats each. The mean bleeding point of rats in the negative control, positive control, and the eel dry extracts in the doses of 100, 200, and 400 $\mathrm{mg} / \mathrm{kg}$ groups were $7.6,2.6,4.2,1$, and 1, while the average $\mathrm{pH}$ of gastric fluid were $4.948,5.182,4.224,2.888$, and 4.890, respectively. The bleeding point of rats in the positive control and the eel dry extracts in the doses of 100,200 , and $400 \mathrm{mg} / \mathrm{kg}$ groups were statistically different from the negative control. There was no correlation between $\mathrm{pH}$ and the onset of bleeding point, and hence $\mathrm{pH}$ could not be used as a parameter for gastric ulceration. It can be concluded that the dry extract of eel at an optimum dose of $200 \mathrm{mg} / \mathrm{kg}$ showed a potential efficacy for the treatment of peptic ulcers.
\end{abstract}

Key words: dry extract, Monopterus albus, peptic ulcer.

\section{Pendahuluan}

Tukak lambung atau Peptic Ulcer

Disease (PUD) merupakan suatu penyakit pada saluran pencernaan yang ditunjukkan dengan terjadinya kerusakan mukosa lambung yang dapat disebabkan oleh sekresi asam lambung berlebih, infeksi Helicobacteria pylori maupun produksi prostaglandin berkurang (Misnadiarly, 2009). Tukak lambung dapat diakibatkan oleh adanya ketidakseimbangan faktor pengiritasi epitel gaster dengan mekanisme pertahanan mukosa lambung. Epitel gaster mengalami infeksi yang dapat diakibatkan oleh dua faktor yaitu faktor perusak endogen dan eksogen. Perusak endogen meliputi asam $(\mathrm{HCl})$, pepsinogen/pepsin, dan garam empedu. Sedangkan faktor perusak eksogen adalah faktor yang berasal dari konsumsi obat-obatan, alkohol, dan bakteri (Setiati et al., 2014).

Peningkatan konsumsi akohol, obat-obat antiinflamasi non-steroid (OAINS) dan diet yang keliru menjadi penyebab meningkatnya penyakit tukak/ulkus di seluruh dunia. Kejadian ulkus peptikum sebesar 15-20\% pertahun terjadi pada pasien yang menggunakan OAINS dengan riwayat penyakit rheumatoid arthtritis dan osteoarthtritis. Terdapat lebih dari setengah pasien yang datang dengan keluhan perdarahan ulkus peptikum atau perforasi dilaporkan adanya penggunaan OAINS secara berulang, salah satunya adalah aspirin. Sehingga ulkus peptikum dianggap sebagai penyakit zaman modern yang timbul seiring dengan 
bertambahnya frekuensi penggunaan obat AINS dan gaya hidup stress (Sofidiya et al., 2012).

Terlepas dari peran asam merusak, spesies oksigen reaktif (Reactive Oxygen Species/ROS) terutama radikal hidroksil (S-OH) memainkan peran utama dalam menyebabkan kerusakan oksidatif mukosa di hampir semua jenis tukak lambung (Phull et al., 1995). Cara pencegahan terbentuknya tukak lambung salah satunya dengan cara pemberian obat yang dapat berfungsi sebagai sitoprotektif pada mukosa lambung (Neal, 2006). Obat sitoprotektif (pelindung mukosa) merupakan obat yang berfungsi sebagai lapisan pelindung mukosa lambung.

Salah satu obat sitoprotektif mukosa lambung yang sering digunakan adalah sukralfat. Penggunaan sukralfat sebagai obat kimia yang digunakan jangka panjang bukan berarti tanpa risiko. Ada efek samping yang ditimbulkan dan perlu mendapat perhatian di antaranya konstipasi, insomnia, gatal-gatal, sakit perut, dan muntah (Santoso, 2017). Oleh sebab itu, perlu dilakukan adanya penelitian mengenai terapi alternatif berbasis bahan alami untuk tukak lambung yang memiliki efek terapetik tinggi, aman dikonsumsi jangka panjang, dan sedikit efek samping atau bahkan tidak menimbulkan efek samping. Obat bahan alam memiliki nilai terapetik dengan toksisitas rendah, sehingga aman digunakan sebagai terapi pengobatan (Bandyopadhyay et al., 1998).
Indonesia merupakan suatu negara kepulauan yang banyak menghasilkan ikan. Sehingga tidak mengherankan apabila ikan merupakan sumber protein hewani yang utama bagi masyarakat terutama di daerah jambi yang memilki sungai batang hari dan banyak anak sungai. Provinsi Jambi dengan luas lahannya sekitar 50 juta km terdiri atas 60\% dataran rendah, 20\% dataran tinggi, dan $20 \%$ daerah pegunungan. Luas lahan perairan umum sekitar 115.000 ha yang terdiri atas sungai, anak sungai, danau, rawa, dan genangan-genangan.

Beberapa jenis ikan telah diketahui aktifitasnya dalam pengobatan, salah satunya ikan gabus. Dari hasil penelitian yang telah dilakukan dilaporkan bahwa ekstrak ikan gabus terbukti dapat mempercepat penyembuhan luka, antinyeri, antifungi, dan antibakteri, antioksidan, antiinflamasi, dan antipiretik, meningkatkan kemampuan kognitif, dan dapat memberikan efek positif pada kelainan jantung dan kanker (Zakaria et al., 2008; Mat Jais et al., 2008; Saleem et al., 2011; Mat Jais et al., 1997).

Ikan gabus dan belut memiliki kandungan albumin, yang diprediksi beraktifitas sebagai antitukak. Albumin merupakan jenis protein terbanyak di dalam plasma yang mencapai kadar $60 \%$ yang bermanfaat untuk pembentukan jaringan sel baru. Di dalam ilmu kedokteran, albumin ini dimanfaatkan untuk mempercepat pemulihan jaringan sel tubuh yang rusak misalnya karena 
operasi atau pembedahan (Manan dan Haruan, 2006).

\section{Metode Penelitian}

Lokasi Penelitian

Penelitian dilaksanakan di Laboratorium Agroindustri dan Lingkungan, Fakultas Sains dan Teknologi, Universitas Jambi.

\section{Alat dan Bahan}

Alat yang digunakan pada penelitian ini meliputi peralatan gelas seperti gelas ukur, spatula, erlenmeyer, beaker glass, pipet filler, pipet volume, dan penyaring. Peralatan pendukung lain yaitu pisau, corong, nampan, panci stainless steel, waterbath, sonde oral, lensa pembesar, $\mathrm{pH}$ meter digital, pengukus, sentrifus, pengepres, vakum evaporator, ayakan 60, cawan petri, freeze drying, kandang hewan percobaan, dan jangka sorong. Sementara itu, bahan-bahan yang digunakan meliputi daging belut, etanol, buah nenas, aspirin, $\mathrm{Na} \mathrm{CMC}$, tikus, $\mathrm{NaCl}$, dan eter.

\section{Jalannya Penelitian}

1. Aklimatisasi hewan percobaan

Tiga puluh ekor tikus jantan yang sehat, umur 2-3 bulan, dengan berat 200-300 g diletakkan dalam kandang. Masing-masing kandang berisi satu ekor tikus. Kandang terbuat dari wadah plastik dengan alas sekam padi dan tutup dari anyaman kawat yang kuat, tahan gigitan, tidak mudah rusak sehingga hewan tidak mudah lepas. Kandang diberi lampu, ditempatkan pada ruangan dengan ventilasi baik, cukup cahaya, tenang, tidak bising. Kandang dibersihkan setiap hari. Tikus diadaptasikan selama tujuh hari dan diberi diet standar dengan menggunakan pemberian makanan dan minuman secara ad libitum. Berat badan ditimbang tiap hari. Setelah aklimasi dipilih persentase perbedaan berat badan hewan tiap hari tidak lebih dari $10 \%$.

2. Rancangan penelitian

Rancangan penelitian yang akan dilakukan untuk uji aktivitas antitukak lambung adalah rancangan acak lengkap (RAL) dengan 5 perlakuan (K-, $\mathrm{K}+, \mathrm{P} 1, \mathrm{P} 2, \mathrm{P} 3)$ dan terdiri dari 25 ekor tikus secara keseluruhan. Langkah pengacakan dilakukan dengan menggunakan pengambilan undian bilangan acak, ditentukan terlebih dahulu nomor urut dari 1 hingga 25 pada satuan-satuan percobaan yang sesuai, kemudian diambil secara acak untuk dikelompokkan menjadi kelompok perlakuan.

3. Preparasi ekstrak belut

Sebanyak $5 \mathrm{~kg}$ belut (berukuran sedang), dicuci dan dibersihkan. Daging belut dipisahkan dari bagian tubuh yang lain (kepala, tulang, dan kulit) dengan cara difillet. Sampel belut yang sudah diolah dipotong kecil-kecil sekitar $1,5 \mathrm{~cm}^{2}$ dan dimasukkan ke dalam dandang atau kukusan berisi satu liter air dan di dalamnya sudah disediakan mangkuk tahan panas. Setelah itu dikukus selama 30 menit dan diatur suhunya pada $40{ }^{\circ} \mathrm{C}$. Kemudian daging belut dibungkus dengan kain dan 
dimasukkan ke dalam alat press hidrolik, dan dilakukan pengepresan. Ekstrak belut disentrifugasi dengan kecepatan 6000 rpm selama 60 menit. Kemudian fase air dan minyak (lapisan bawah) diambil dan dibuang pengotornya dengan cara disaring.

Ekstrak belut yang diperoleh diuapkan sampai kering dengan menggunakan evaporator vakum suhu $49{ }^{\circ} \mathrm{C}$ selama 10 jam (Yuniarti et al., 2013). Serbuk kering yang diperoleh ditimbang. Selanjutnya dilakukan penggilingan menggunakan blender dan pengayakan 60 mesh.

4. Pembuatan larutan suspensi aspirin

Tablet aspirin ditimbang satu per satu, kemudian dihitung bobot rataratanya. Semua tablet dimasukkan ke dalam lumpang dan digerus hingga halus dan homogen, kemudian disuspensikan dalam Na CMC $1 \%$ dan diaduk hingga homogen. Dosis yang digunakan untuk penginduksi adalah $1000 \mathrm{mg} / \mathrm{kgBB}$.

Perlakuan yang akan diberikan adalah pemberian secara oral Sebelum diberi perlakuan, terlebih dahulu semua kelompok hewan diadaptasikan dengan lingkungan barunya selama seminggu dan diberi makan dan minum secukupnya. Sebelum pengujian, hewan uji terlebih dahulu dipuasakan selama kurang lebih 12 jam dengan tetap diberi air minum. Pada hari pertama seluruh hewan coba diinduksi dengan aspirin dosis $1000 \mathrm{mg} / \mathrm{kgBB}$ dan 12 jam kemudian masing-masing kelompok diberi perlakuan sebagai berikut:

a. Kelompok I (kontrol negatif) Tikus jantan hanya diberi diberikan $\mathrm{Na} \mathrm{CMC} 0,5 \%$

b. Kelompok II (kontrol positif)

Tikus jantan diberi sukralfat dengan dosis $500 \mathrm{mg} / \mathrm{kgBB}$ secara oral.

c. Kelompok III (P1)

Tikus jantan diberi ekstrak kering belut dengan dosis $0,1 \mathrm{~g} / \mathrm{kgBB}$ secara oral.

d. Kelompok IV (P2)

Tikus jantan diberi ekstrak kering belut dengan dosis $0,2 \mathrm{~g} / \mathrm{kgBB}$ secara oral.

e. Kelompok V (P3)

Tikus jantan diberi ekstrak kering belut dengan dosis $0,4 \mathrm{~g} / \mathrm{kgBB}$ secara oral.

Perlakuan tersebut dilakukan satu kali sehari selama tiga hari. Pada hari selanjutnya hewan uji disiapkan untuk dilakukan penentuan jumlah tukak dan titik pendarahan. Hewan uji dipuasakan terlebih dahulu selama 12 jam, selanjutnya semua hewan percobaan dibedah. Pertama-tama hewan dibius menggunakan eter dan dilanjutkan dengan dislokasi leher. Perut tikus dibedah secara hati-hati diambil organ lambungnya, dan disuntikkan $2 \mathrm{~mL} \mathrm{NaCl}$ fisiologis. Organ lambung dibuka di sepanjang kurvatura mayor, dan ditampung cairan ke dalam tabung reaksi. Lambung dicuci dengan natrium klorida $0,9 \%$ lalu direntangkan untuk mempermudah melihat tukak dan 
menghitung jumlah titik pendarahan. Penentuan $\mathrm{pH}$ lambung dilakukan dengan cara isi lambung dikumpulkan dan disentrifugasi pada $1000 \mathrm{rpm}$ selama 10 menit. Cairan supernatan diambil $1 \mathrm{~mL}$ dan didilusi dengan 10 $\mathrm{mL}$ air suling. $\mathrm{pH}$ larutan diukur menggunakan $\mathrm{pH}$ meter. Pengukuran dilakukan dengan pemeriksaan adanya tukak dan jumlah pendarahan yang terbentuk serta $\mathrm{pH}$ lambung setelah perlakuan.

5. Penentuan tukak dan titik pendarahan

Adanya aktifitas antitukak lambung dapat dilihat dari perbandingan terbentuknya pendarahan. Satu tukak dinilai dengan 5 titik pendarahan.

6. Analisis data

Parameter yang diukur pada penelitian ini adalah jumlah titik tukak dan titik pendarahan. Satu tukak dikonversi menjadi 5 titik pendarahan. Jika sebaran data pada sebuah kelompok data terdistribusi normal/uji normalitas (uji Kolmogorov Smirnov) maka digunakan uji statistik parametrik. Sesuai dengan variabel yang diukur maka dapat menggunakan uji Anova satu arah, dan dilanjutkan dengan uji homogenitas (uji Levene). Jika terdapat perbedaan yang signifikan antar kelompok, maka dilanjutkan uji lanjut/post hoc (uji Bonferroni jika data homogen dan uji Dunnet c jika data tidak homogeny, dan jika jumlah setiap kelompok tidak sama menggunakan uji Schefe). Jika data belum normal maka data mengikuti uji nonparametrik. Uji yang dapat digunakan untuk melihat perbedaan antar kelompok yaitu uji Kruskal Walis dan jika berbeda signifikan dilanjutkan dengan uji Wilcoxon. Uji korelasi $\mathrm{pH}$ dengan titik pendarahan menggunakan uji korelasi Pearson.

\section{Hasil dan Pembahasan}

Daging belut $5000 \mathrm{~g}$ diekstraksi dan diperoleh 7,73 g ekstrak kering belut. Dari hasil penelitian diperoleh data jumlah titik pendarahan dan $\mathrm{pH}$ lambung pada tiap kelompok perlakuan, lalu data jumlah tukak dikonversi menjadi titik pendarahan, dengan nilai konversi satu tukak sama dengan 5 titik pendarahan. Hasil rata-rata titik pendarahan dan $\mathrm{pH}$ dapat dilihat pada Gambar 1-2.

Gambar 1 dan 2 menunjukkan rata-rata jumlah titik pendarahan yang terbentuk dan $\mathrm{pH}$ lambung setelah perlakuan. Grafik 1 terlihat bahwa ratarata titik pendarahan kelompok kontrol negatif jauh lebih banyak dari pada kontrol positif, P1, P2, dan P3. Juga dapat dilihat bahwa jumlah titik pendarahan P2 dan P3 lebih rendah dari pada kontrol positif yang dalam hal ini menggunakan obat sintetis sukralfat. Artinya aktifitas P2 dan P3 mampu menyaingi obat antitukak lambung yang beredar di pasaran. 


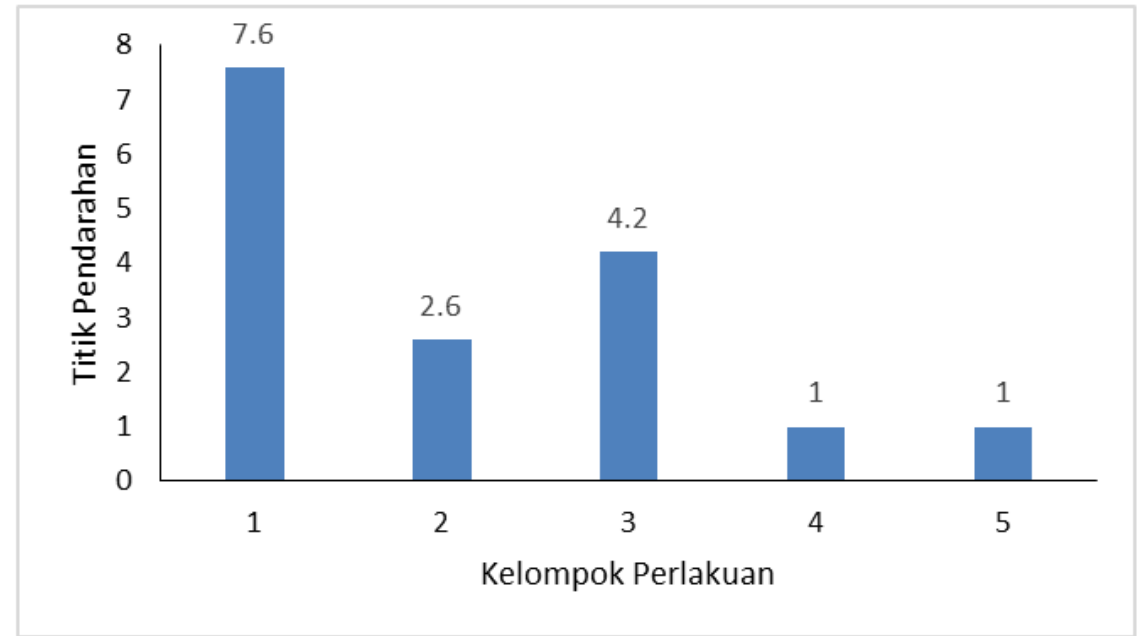

Gambar 1. Rata-rata titik pendarahan tiap kelompok .

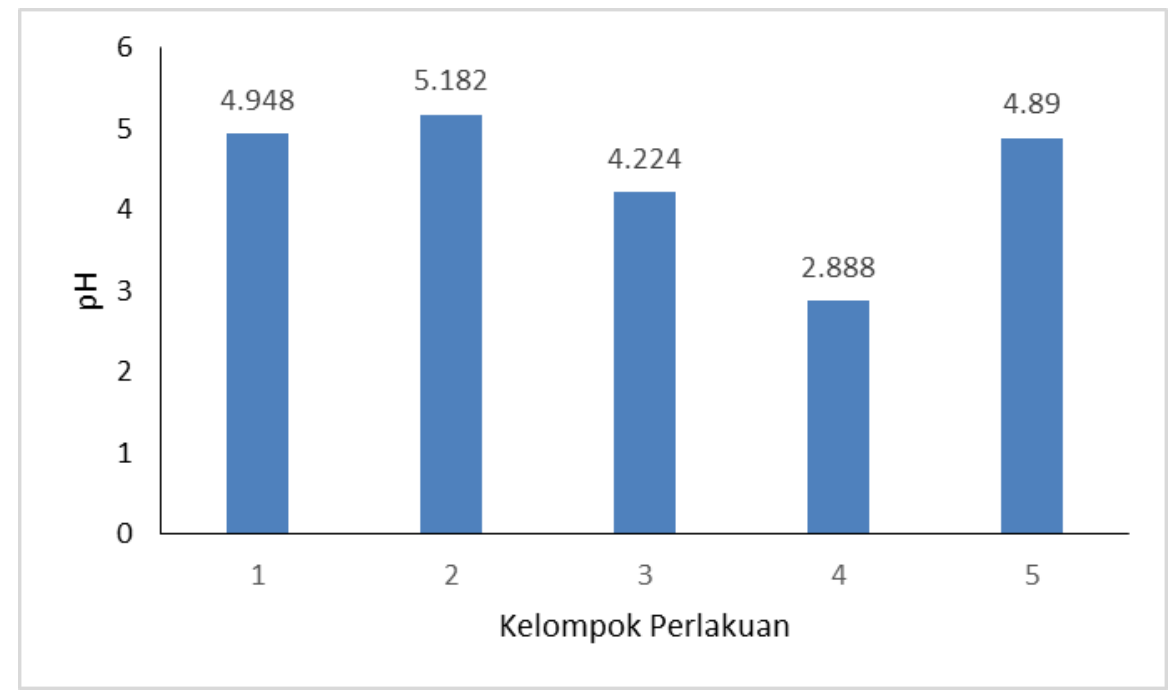

Gambar 2. Rata-rata pH tiap kelompok.

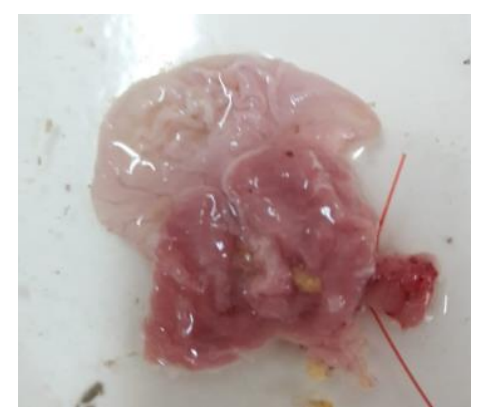

Gambar 3. titik pendarahan. 
Gambar 3 menunjukkan titik pendarahan yang terbentuk setelah pemberian penginduksi dan pemberian obat. Dari gambar tersebut terlihat bahwa tukak yang terbentuk lebih lebar dan jelas ada luka yang agak dalam serta titik pendarahan yang tidak hilang meski telah dibersihkan menggunakan $\mathrm{NaCl}$ fisiologis.

Dari uji statistik menggunakan uji Anova satu arah terlihat bahwa pada jumlah titik pendarahan nilai sig $0,00<0,05$ yang berarti terdapat perbedaan yang signifikan pada antar kelompok perlakuan. Untuk melihat perbedaannya pada masing-masing kelompok digunakan uji lanjut, yaitu uji Benferoni. Dari uji Benferoni, terlihat bahwa pada jumlah titik pendarahan terdapat perbedaan yang signifikan antara kelompok kontrol negatif dengan semua perlakuan yang ditandai dengan sig $<0,05$. Artinya ekstrak kering belut memiliki aktifitas dalam penyembuhan tukak lambung. Jika dibandingkan dengan sediaan yang di pasaran (sukralfat), secara statistik tidak terdapat perbedaan jumlah titik pendarahan secara nyata antara kelompok kontrol positif dengan pemberian ekstrak kering belut, yang artinya pengobatan dengan ekstrak kering belut dengan dosis rendah telah menyaingi sediaan tukak lambung yang beredar di pasaran. Pada dosis pemberian ekstrak kering belut dosis 100 $\mathrm{mg} / \mathrm{kgBB}$ memiliki aktifitas pengobatan tukak lambung berbeda secara signifikan dengan dosis pemberian $200 \mathrm{mg} / \mathrm{kgBB}$ dan $400 \mathrm{mg} / \mathrm{kgBB}$ sedangkan pada dosis $200 \mathrm{mg} / \mathrm{kgBB}$ dengan $400 \mathrm{mg} / \mathrm{kgBB}$ tidak memiliki aktifitas pengobatan tukak lambung yang berbeda secara signifikan. Artinya dosis 200 mg/kgBB ekstrak belut kering merupakan dosis terbaik memberikan aktifitas antitukak lambung, karena dosis yang lebih rendah akan memiliki efek samping yang lebih rendah jika dibandingkan dengan dosis 400 $\mathrm{mg} / \mathrm{kgBB}$ yang lebih tinggi.

Uji yang sama juga dilakukan oleh Khan et al. (2014) pada ekstrak air ikan gabus, dimana peneliti menggunakan penginduksi aspirin. Dari hasil penelitian disimpulkan bahwa semua dosis uji ekstrak air ikan gabus menurunkan indeks ulkus dibandingkan dengan obat standar. Pengujian Pearson antara $\mathrm{pH}$ dengan jumlah pendarahan terlihat bahwa tidak ada korelasi $\mathrm{pH}$ dengan terjadinya pendarahan $(0,125>0,05)$. Artinya, $\mathrm{pH}$ lambung tidak dapat dijadikan parameter terjadinya tukak lambung. Ini disebabkan oleh banyak faktor yang menyebabkan perubahan $\mathrm{pH}$ lambung, seperti asupan protein yang mengeksresikan asam lambung lebih banyak sehingga $\mathrm{pH}$ lambung menjadi menurun, tetapi ini bertujuan untuk memecah makanan/protein sehingga lebih mudah untuk diserap.

\section{Simpulan}

Dosis $200 \mathrm{mg} / \mathrm{kgBB}$ ekstrak kering belut merupakan dosis terbaik yang memberikan aktifitas antitukak lambung pada tikus yang diinduksi aspirin. 


\section{Ucapan Terima Kasih}

Terima kasih kepada LPPM
Universitas Jambi yang telah
memberikan dana penelitian, serta
semua pihak yang telah membantu
sehingga terselesaikannya penelitian ini.

\section{Daftar Pustaka}

Bandyopadhyay, U., Chattopadhyay, I., Biswas, K., Maity, P., Banerje, R.K. 1998. Indomethacin inactivates gastric peroxidase to induce reactive-oxygenmediated gastric mucosal injury and curcumin protects it by preventing peroxidase inactivation and scavenging reactive oxygen. Free Radical Biology and Medicine, 40(8):1397-1408.

Khan, M.S.A., Jais, A.M.M., Hussain, J., Siddiqua, F., Reddy, A.G., Shivakumar, P., Madhuri, D. 2014. Gastroprotective effect of freeze dried stripped snakehead fish (Channa striata Bloch.) aqueous extract against aspirin induced ulcerogenesis in pylorus ligated rats. ISRN pharmacology, 2014:327606.

Manan A, Haruan A. 2006. Fresh Water Wound Healer. Malaysia: University of Putra Malaysia.

Mat Jais, A.M., Dambisya, Y.M., Lee, T.L. 1997. Antinociceptive activity of Channa striatus (haruan) Extracts in Mice. Journal of Ethnopharmacology, 57(2):125130.

Mat Jais, A.M., Zakaria, Z.A., Luo, A., Song, Y.X. 2008. Antifungal activity of Channa striatus (haruan) crude extracts. International Journal of Tropical Medicine, 3(3):43-48.

Misnadiarly. 2009. Mengenal Penyakit Organ Cerna: Gastritis (Dyspepsia atau Maag). Jakarta: Pustaka Populer OBDA.

Neal, M.J. 2006. Obat yang bekerja pada saluran gastrointestinal. $\mathrm{Di}$ dalam Glance Farmakologi Medis. Edisi ke-5. Jakarta: Penerbit Erlangga.

Phull, P.S., Green, C.J., Jacyna, M.R. 1995. A radical view of stomach: the role of oxygen-derived free radicals in gastroduodenal disease. European Journal of Gastroenterology \& Hepatology, 7:265-274.

Saleem, A.M., Hidayat, M.T., Jais, M., Fakurazi, S., Moklas, M., Sulaiman, M.R., Amom, Z. 2011. Antidepressant-like effect of aqueous extract of Channa striatus fillet in mice models of depression. European Review for Medical and Pharmacological Sciences, 15:795-802.

Santoso, J. 2017. Efektivitas infusa rimpang kunyit (Curcuma Domestica Val.) sebagai gastroprotektor pada tikus dengan model tukak lambung. Jurnal Permata Indonesia, 8(1):34-44.

Setiati, S., Sudoyo, A.W., Alwi, I., Simadibrata, M., Setiyohadi, B., Syam, F.A. 2014. Buku Ajar IImu Penyakit Dalam. Edisi 6. Jakarta: Interna 
Sofidiya, M.O., Agufobi, L., Akindele, A. J., Olowe, J.A., Familoni, O.B. 2012. Effect of Flabellaria paniculata Cav. extracts on gastric ulcer in rats. Complementary \& Alternative Medicine, 12:168.

Yuniarti, D.W., Sulistiyati, T.D. Suprayitno, E. 2013. Pengaruh suhu pengeringan vakum terhadap kualitas serbuk albumin gabus (Ophiocephalus Striatus). Thpi Student Journal, 1(1):1-9.
Zakaria, Z.A., Kumar, G.H., Mat Jais, A.M., Sulaiman, M.R., Somchit, M.N. 2008. Antinociceptive, antiinflammatory, and antipyretic properties of Channastriatus fillet aqueous and lipid-based extracts in rats. Methods and Finding in Experimental and Clinical. Pharmacology, 30(5):355-362. 